Pesq. Vet. Bras. 30(3):237-242, março 2010

\title{
Ocorrência de paratuberculose em búfalos (Bubalus bubalis) em Pernambuco ${ }^{1}$
}

\author{
Rinaldo A. Mota ${ }^{2 *}$, Paulo V. Peixoto ${ }^{3}$, Elise M. Yamasaki ${ }^{4}$, Elizabeth S. de \\ Medeiros ${ }^{5}$, Mateus M. da Costa ${ }^{6}$, Rodolfo M. Peixoto ${ }^{7}$ e Marilene F. Brito ${ }^{8}$
}

\begin{abstract}
Mota R.A., Peixoto P.V., Yamasaki E.M., Medeiros E.S., Costa M.M., Peixoto R.M. \& Brito M.F. 2010. [Occurrence of paratuberculosis in buffaloes (Bubalus bubalis) in Pernambuco.] Ocorrência de paratuberculose em búfalos (Bubalus bubalis) em Pernambuco. Pesquisa Veterinária Brasileira 30(3):237-242. Departamento de Medicina Veterinária, Universidade Federal Rural de Pernambuco, Recife, PE 52171-900, Brazil. E-mail: rinaldo.mota@ hotmail.com

Paratuberculosis (PTB) is a disease of great economical importance for ruminant in several countries and represents a threat to the development of Brazilian livestock. The contagious disease caused by chronic PTB leads to incurable granulomatous enterocolitis of difficult control. PTB is caused by the Mycobacterium avium subsp. paratuberculosis (MAP). No record on the occurrence of paratuberculosis in buffaloes in Brazil could be found. Five of 100 buffaloes in a herd in Pernambuco-Brazil showed clinical signs characteristic of PTB. At necropsy, of two animals the lesions were restricted to the small intestine with thickening and corrugation of the mucosa, increase of mesenteric lymph nodes and prominent lymph vessels. Histopathology revealed granulomatous inflammation infiltrated with numerous epithelioid macrophages, Langhans type giant cells, and clusters of Ziehl-Neelsen (ZN) positive organisms within the intestinal mucosa. In the mesenteric lymph nodes there was thickening of the capsule and marked granulomatous inflammation. Smears of feces and scrapping smears were prepared from intestinal mucosa and cut surface of mesenteric lymph nodes and, stained by the Ziehl-Neelsen method for research of acid fast bacilli, with positive results. Lymph nodes and intestinal mucosa revealed at IS900 specific polymerase chain reaction amplification of a fragment of about $110 \mathrm{pb}$, confirmed by the comparison with other sequences of $M$. avium subsp. paratuberculosis available in GenBank.
\end{abstract}

INDEX TERMS: Paratuberculosis, buffaloes, Mycobacterium avium subsp. paratuberculosis, Johne's disease, clinics, pathology.

\footnotetext{
${ }^{1}$ Recebido em 17 de julho de 2009.

Aceito para publicação em 27 de outubro de 2009.

2 Departamento de Medicina Veterinária, Universidade Federal Rural de Pernambuco (UFRPE), Rua Dom Manoel de Medeiros s/n, Dois Irmãos, Recife, PE 52171-900, Brasil. *Autor para correspondência: rinaldo.mota@ hotmail.com

${ }^{3}$ Departamento de Nutrição Animal e Pastagem, Instituto de Zootecnia, Universidade Federal Rural do Rio de Janeiro (UFRRJ), Seropédica, RJ 23890-000, Brasil.

${ }^{4}$ Mestranda do Curso de Pós-Graduação em Medicina Veterinária, UFRRJ, Seropédica, RJ.

${ }^{5}$ Doutoranda do Programa de Pós-Graduação em Biociência Animal, UFRPE, Recife, PE.

6 Laboratório de Microbiologia e Imunologia Animal, Universidade Federal do Vale do São Francisco (Univasf), Rua José de Sá Maniçoba s/n, Centro, Petrolina, PE 56304-205, Brasil.

${ }^{7}$ Mestrando do Curso de Pós-Graduação em Ciência Animal, Univasf, Petrolina, PE.

8 Departamento de Epidemiologia e Saúde Pública, Instituto de Veterinária, UFRRJ, Seropédica, RJ.
}

RESUMO.- A paratuberculose (doença de Johne) é uma das doenças de maior importância econômica para ruminantes em vários países e pode representar uma ameaça ao desenvolvimento da pecuária brasileira. É uma doença infecto-contagiosa que provoca enterocolite granulomatosa crônica, incurável e de difícil controle, cujo agente é o Mycobacterium avium subsp. paratuberculosis (MAP). Descreve-se a ocorrência de paratuberculose em um rebanho de búfalos no Estado de Pernambuco, Brasil. Não foi encontrado registro, na literatura, da ocorrência de paratuberculose em búfalos no país. De 100 búfalos, cinco mostravam sinais clínicos característicos da doença. À necropsia de dois animais as lesões estavam restritas ao intestino delgado com evidente espessamento da mucosa, aumento de linfonodos mesentéricos e vasos linfáticos proeminentes e dilatados. À microscopia, observaram-se na mucosa do intestino, infiltrado inflamatório granulomatoso 
com numerosos macrófagos epitelióides e células gigantes de Langhans, além de bacilos álcool-ácido resistentes (BAAR) visualizados através da coloração de Ziehl-Neelsen (ZN). Nos linfonodos mesentéricos, havia espessamento da cápsula e marcada inflamação granulomatosa. $O$ exame direto pela técnica de $\mathrm{ZN}$ para pesquisa do bacilo em esfregaços de fezes, raspado de mucosa intestinal e imprint de linfonodos mesentéricos resultou positivo. A PCR IS900 específico de linfonodo mesentérico e mucosa intestinal revelou amplificação de um fragmento de aproximadamente $110 \mathrm{pb}$, confirmada pela comparação com outras sequências de $M$. avium subsp. paratuberculosis disponíveis no GenBank.

TERMOS DE INDEXAÇÃO: Paratuberculose, búfalos, Mycobacterium avium subsp. paratuberculosis, doença de Johne, clínica, patologia.

\section{INTRODUÇÃO}

No Brasil, a paratuberculose (doença de Johne) tem sido diagnosticada em vários Estados, porém, não se encontrou descrição sobre a ocorrência dessa doença em búfalos; todos os casos descritos se referem à enfermidade em bovinos. O primeiro registro de paratuberculose em bovino no país foi feito por Dupont (1915), no Rio de Janeiro. Mais tarde a enfermidade foi descrita nos Estados do Rio de Janeiro (Santos \& Silva, 1956, Ferreira et al. 2001), Rio Grande do Sul (Ramos et al. 1986, Driemeier et al. 1999, Gomes et al. 2002), Santa Catarina (Portugal et al. 1979), Minas Gerais (Nakajima et al. 1991), São Paulo (Brautingam et al. 1996, Fonseca et al. 2000), Mato Grosso do Sul (Brautingam et al. 1996, Oliveira et al. 2008), Paraíba (Dias et al. 2002), Goiás (Acypreste et al. 2005), Pará (Silva 2005) e Pernambuco (Mota et al. 2007).

Trata-se de uma doença infecto-contagiosa que acomete ruminantes domésticos e selvagens e é caracterizada por uma enterite granulomatosa crônica causada por Mycobacterium avium subsp. paratuberculosis (MAP), um bacilo álcool-ácido resistente.

A infecção se dá pela ingestão de colostro, leite ou água contaminados com fezes que contêm o microrganismo. A doença clínica se manifesta apenas na vida adulta, geralmente após três anos de infecção subclínica. Os animais clinicamente acometidos apresentam diarréia profusa, perda de peso, desidratação, caquexia e morte e as lesões localizam-se principalmente no trato intestinal e linfonodos mesentéricos. As perdas econômicas verificadas em função da infecção subclínica se devem à redução da conversão alimentar, diminuição da produtividade, redução dos níveis de proteína e gordura no leite, perda de peso ao abate, alta incidência de mastite e diminuição da fertilidade (Clarke 1997).

O quadro clínico-patológico da paratuberculose em búfalos relatado na Î́ndia (Sivakumar et al. 2006) e na Itália (Lillini et al. 1999) não difere substancialmente daquele descrito para os bovinos.

O objetivo deste trabalho é registrar a ocorrência natural da paratuberculose em búfalos no Estado de
Pernambuco, Brasil e caracterizar os achados clínicopatológicos da enfermidade nessa espécie.

\section{MATERIAL E MÉTODOS}

Foram colhidos dados epidemiológicos e clínicos junto ao proprietário, em uma fazenda de bubalinos no Estado de Pernambuco, onde ocorria a doença. Após o estudo clínico em cinco animais que mostravam sinais característicos de paratuberculose, foram feitos esfregaços de fezes, nos quais se utilizou a técnica de Ziehl-Neelsen para a pesquisa dos bacilos álcool-ácido resistentes (BAAR). Realizou-se a necropsia de dois animais e fragmentos de diversos órgãos, linfonodos mesentéricos e intestinos delgado e grosso foram coletados, fixados em formol a $10 \%$ tamponado e processados no Laboratório de Histopatologia do Setor de Anatomia Patológica do Projeto Sanidade Animal Embrapa/UFRRJ. As amostras foram rotineiramente processadas e incluídas em parafina, cortadas à espessura de $5 \mu$ e coradas com hematoxilina-eosina (HE) e Ziehl-Neelsen. Essa coloração também foi usada para a pesquisa de BAAR em imprint de linfonodos mesentéricos e em raspados de mucosa dos intestinos delgado e grosso.

Para confirmação da presença de Mycobacterium avium subsp. paratuberculosis foi utilizada PCR (reação de polimerase em cadeia) espécie específica com os iniciadores DF e DR2 para amplificação de sequências específicas IS900-like de acordo com descrições de Taddei et al. (2008). O DNA total foi extraído das amostras de linfonodo e mucosa intestinal pelo método de CTAB, conforme descrições de Sambrook \& Russell (2001). Para a PCR, $2 \mathrm{ml}$ do DNA foram aplicados em $48 \mathrm{ml}$ do mix contendo $15 \mathrm{pmol}$ dos iniciadores, $200 \mathrm{mM}$ dos desoxirribonucleotídeos, tampão de Taq $1 \times$ e 5 U de Taq (Cenbiot, UFRGS). Essa mistura foi levada ao termociclador e submetida a um ciclo inicial de desnaturação a $96^{\circ} \mathrm{C}$ por 5 minutos, seguidos de 30 ciclos constituídos de um minuto a $95^{\circ} \mathrm{C}$, um minuto a $62^{\circ} \mathrm{C}$ e um minuto a $72^{\circ} \mathrm{C}$. O resultado da PCR foi verificado em gel de agarose a $1 \%$, corado com brometo de etídio. A identidade dos produtos foi confirmada por sequenciamento do DNA em um equipamento MegaBace $500^{9}$. A reação de terminação de cadeia foi implementada com o uso do kit DYEnamic ET ${ }^{10}$. As sequências obtidas foram com as depositadas no GenBank (Benson 2002), pelo programa BLASTn.

\section{RESULTADOS}

Epidemiologia e sinais clínicos. Na propriedade visitada havia 100 animais e cinco mostravam sintomas evidentes da doença. Esses animais permaneciam em currais coletivos e se alimentavam em cochos coletivos. No rebanho, eram frequentes enfermidades concomitantes, tais como mastite clínica e subclínica, diarréia em bezerros e verminose. O proprietário relatou que os animais apresentavam diarréia crônica profusa, aquosa e enegrecida, por vezes sob forma de jatos e refratária ao tratamento antimicrobiano parenteral, à base de tetraciclina, sulfa e penicilina. Além da diarréia, foram observados emagrecimento progressivo e queda na produção de

\footnotetext{
${ }^{9}$ Amershan Biosciences, Amershan Biosciences do Brasil Ltda, Rua Domingos Marchetti 192, Bairro do Limão, São Paulo, SP 02712-150.

10 GE Health Care do Brasil Ltda, Rua Domingos Marchetti 192, Bairro do Limão, São Paulo, SP 02712-150.
} 


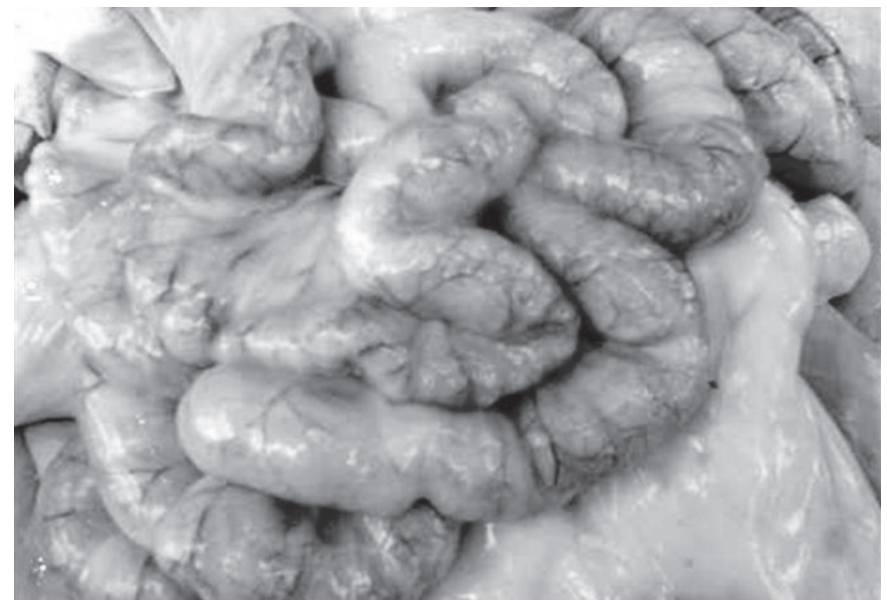

Fig.1. Parede do intestino delgado avermelhada e espessada, na paratuberculose em búfalo.

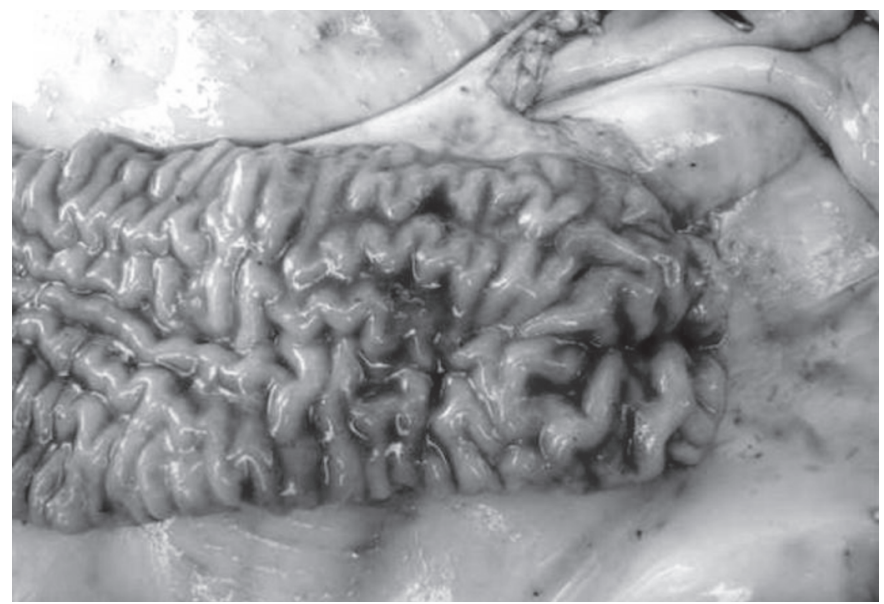

Fig.2. Evidente espessamento e pregueamento da mucosa intestinal com presença de conteúdo líquido amarronzado, na paratuberculose em búfalo.

leite, mesmo com alimentação adequada. $\mathrm{O}$ apetite permanecia normal.

Achados de necropsia. Os animais necropsiados se apresentavam muito magros. As lesões de necropsia estavam restritas ao intestino delgado com evidente espessamento e pregueamento da mucosa em todo o trajeto observado (Fig.1-2) e conteúdo líquido amarronzado na luz intestinal. Havia marcado aumento de toda a cadeia de linfonodos mesentéricos (Fig.3) e vasos linfáticos proeminentes e dilatados.

Histopatologia. Na mucosa do intestino delgado, observou-se infiltrado inflamatório granulomatoso, numerosos macrófagos epitelióides e células gigantes de Langhans por toda extensão, com maior intensidade na porção medial e na extremidade das vilosidades (Fig.4). Em algumas áreas, nas quais a infiltração inflamatória era menos extensa, observaram-se ninhos de células mononucleares, especialmente linfócitos, que se alternavam com focos de macrófagos epitelióides e células gigantes, além da presença de alguns eosinófilos. Neutrófilos eram visualizados em pe-

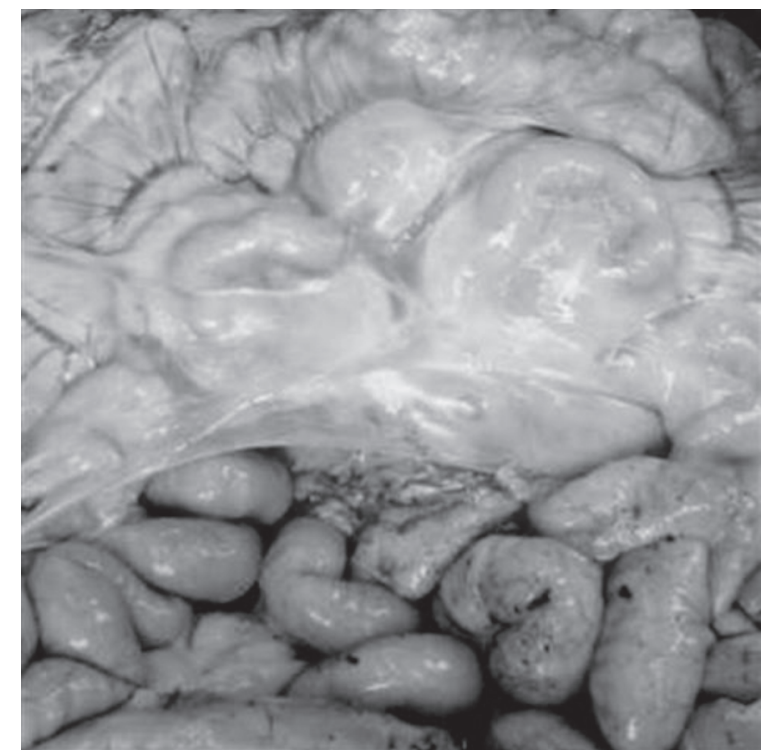

Fig.3. Marcado aumento da cadeia de linfonodos mesentéricos, na paratuberculose em búfalo.

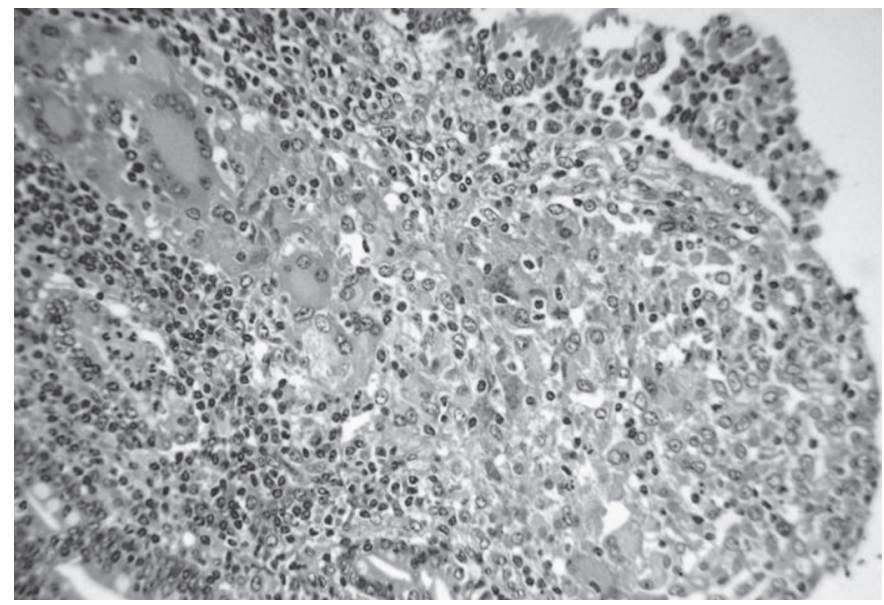

Fig.4. Distensão do ápice da vilosidade do intestino delgado por infiltrado inflamatório granulomatoso, rico em macrófagos epitelióides e células gigantes de Langhans, na paratuberculose em búfalo. HE, obj.16x.

quenos focos ou dispersos no interstício. O lúmen de algumas criptas intestinais estava preenchido por células epiteliais necróticas, plasmócitos e, em menor proporção, neutrófilos. Eventualmente, alguns vasos linfáticos estavam dilatados. Na submucosa, havia espessamento devido à moderada infiltração inflamatória linfoplasmocitária, com presença de mastócitos, raros eosinófilos, moderada proliferação fibroblástica, perivasculite, linfangite granulomatosa e linfangiectasia. A inflamação se estendia até as camadas muscular e serosa, onde se observavam focos de infiltração linfoplasmocitária, por vezes com macrófagos epitelióides entre os feixes musculares e perivasculite, perilinfangite e linfangiectasia. Ainda foram observadas hiperplasia dos feixes nervosos do plexo mioentérico (de Auerbach) e infiltração linfoplasmocitária. No intestino gros- 
so, as lesões eram de mesma natureza, porém menos extensas. Nos linfonodos mesentéricos, havia espessamento da cápsula e marcada inflamação granulomatosa caracterizada por grandes focos de macrófagos epitelióides e numerosas células gigantes de Langhans (Fig.5), desde a região subcortical até os seios medulares; na região medular se observaram proliferação fibroblástica e linfangiectasia. No fígado, havia pequenos focos de inflamação linfoplasmocitária sob forma de nódulos distribuídos aleatoriamente por todo o parênquima. No baço, havia proliferação de células reticulares no centro dos folículos linfóides e moderada hemossiderose. Nos demais órgãos examinados não havia alterações significativas.

A coloração por ZN revelou BAAR no interior de macrófagos epitelióides e de células gigantes na mucosa do

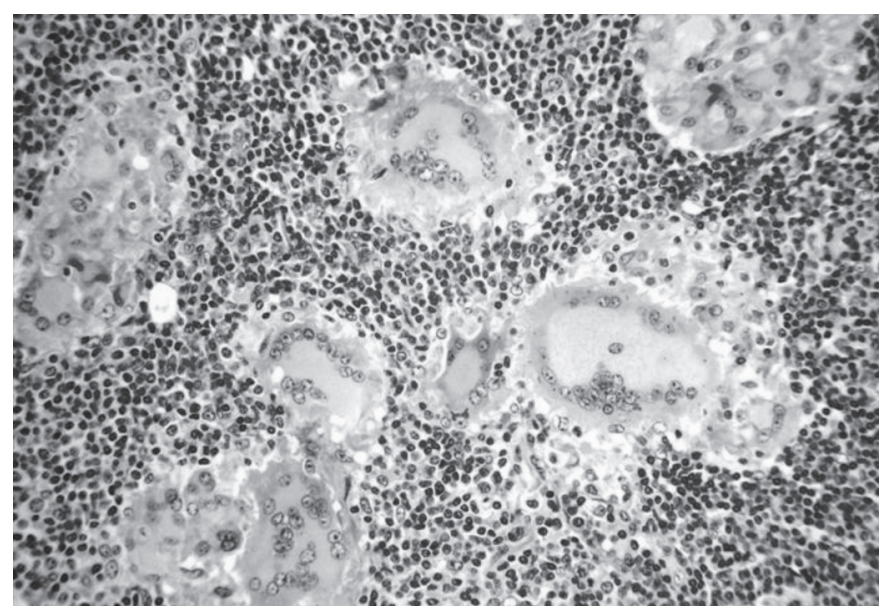

Fig.5. Região cortical de linfonodo mesentérico com grandes focos de macrófagos epitelióides e numerosas células gigantes de Langhans, na paratuberculose em búfalo. HE, obj.16x.

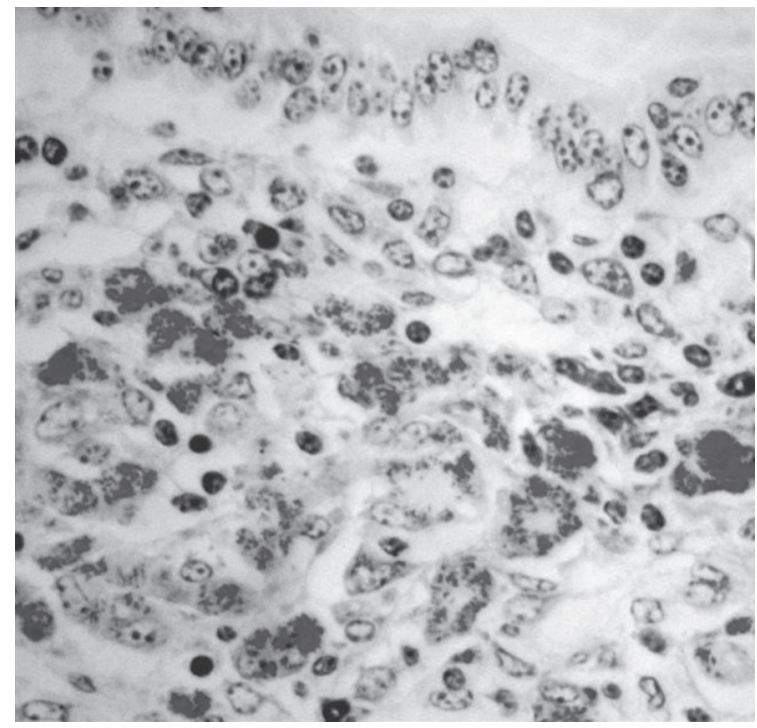

Fig.6. Mucosa do intestino delgado com BAAR no interior de macrófagos epitelióides e de células gigantes, na paratuberculose em búfalo. Ziehl Neelsen, obj.40x.

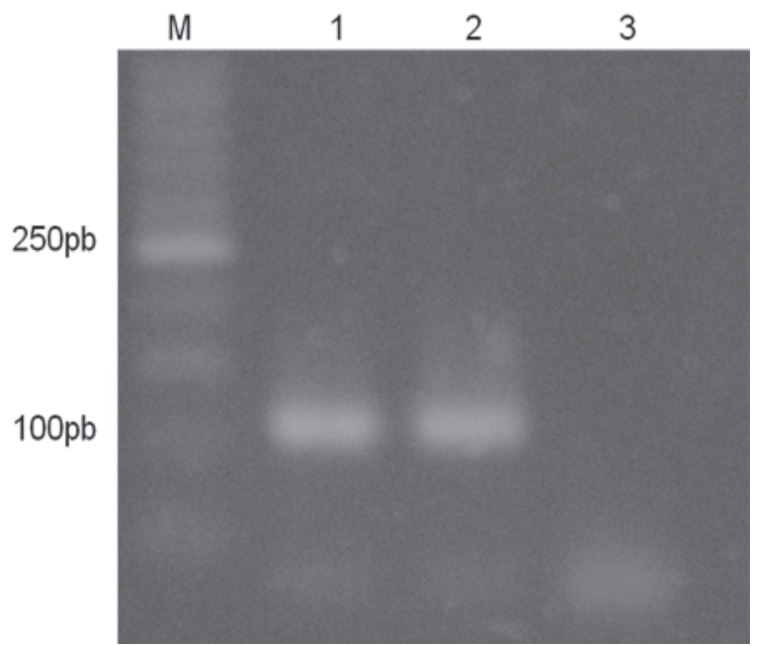

Fig.7. Gel de agarose com os produtos de amplificação por PCR, do gene IS900-like (110pb) de Mycobacterium avium subsp. paratuberculosis. (M) Marcador de massa molecular de 50pb; (1) amostra de mucosa intestinal; (2) amostra de linfonodo;

(3) controle negativo. Paratuberculose em búfalo.

intestino delgado (Fig.6) e nos linfonodos mesentéricos. Não foram observados bacilos nos fragmentos de intestino grosso, fígado e baço examinados.

Exame direto. $\mathrm{O}$ exame direto pela técnica de $\mathrm{ZN}$ em esfregaços de fezes, raspado de mucosa intestinal e imprint de linfonodos mesentéricos apresentou resultados positivos.

PCR. Verificou-se a amplificação de um fragmento de aproximadamente 110pb (Fig.7), conforme descrições de Taddei et al. (2008), tanto nas amostras de linfonodo quanto nas de mucosa intestinal. A identidade do fragmento foi confirmada pela comparação com outras sequências de M. avium subsp. paratuberculosis disponíveis no GenBank.

\section{DISCUSSÃO}

Neste estudo fica caracterizada e confirmada a ocorrência natural da doença de Johne em um rebanho de búfalas leiteiras no Estado de Pernambuco, Brasil através dos dados clínico-epidemiológicos, achados anátomo-histopatológicos e moleculares. A doença de Johne é um dos principais problemas sanitários de ruminantes domésticos e selvagens em países desenvolvidos (Manning \& Collins 2001, Cventnic et al. 2002). Entre os grandes ruminantes, a doença foi diagnosticada em bovinos, bisões, camelídeos e cervídeos (Buergelt et al. 1978, Kramsky et al. 2002).

A enfermidade foi relatada em búfalos na Itália (Lillini et al. 1999) e na Índia; neste último, a incidência registrada foi de 3,6\% (Kulshrestha et al. 1980). Raut et al. (2003) relataram prevalência de $8,6 \%$ no teste alérgico em búfalos aparentemente sadios em diferentes rebanhos, também na Índia. Nesse país, a doença é responsável por consideráveis perdas econômicas relativas a reduções na produção de leite e carne.

No Brasil, apesar da bubalinocultura ter destaque econômico em determinadas regiões do país, a enfermidade 
não havia sido descrita até o momento. Em contrapartida, há queixas de doenças intestinais que cursam com diarréia crônica, perda de peso e queda nos níveis de produção de leite e carne em algumas propriedades de exploração leiteira de alguns Estados da Região Nordeste do país. Acredita-se que a enfermidade esteja presente também em outras propriedades do Estado de Pernambuco, pois as movimentações de compra e venda de animais entre os produtores dessas regiões é um fator de risco para a entrada de animais infectados ou doentes nos rebanhos.

O manejo adotado nas propriedades que utilizam os búfalos para exploração de leite também é importante na disseminação do MAP nas propriedades. Na propriedade visitada, os animais eram manejados em currais e cochos coletivos. Os animais com sinais clínicos da doença apresentavam diarréia profusa que propicia a contaminação da água e dos alimentos oferecidos nos cochos. Diarréia crônica, queda nos níveis de produção de leite e debilidade, descritos com frequência na paratuberculose em bovinos também foram observados nesses búfalos.

As alterações macroscópicas observadas nesse estudo foram similares às descritas na paratuberculose bovina. Os achados histológicos característicos, evidenciados pelas colorações HE e ZN permitiram assegurar o diagnóstico. O exame histopatológico do tecido intestinal, quando inclui a válvula íleo-cecal, é considerado como uma técnica de elevado valor diagnóstico (Clarke 1997). O exame direto por meio da coloração de ZN é uma prova rápida, sensível e econômica para o diagnóstico em esfregaços fecais e em tecidos. A técnica oferece bons resultados dependendo da presença de agregados de BAAR, que podem ser excretadas de forma intermitente. Em casos mais avançados, as micobactérias adotam uma associação característica de grumos, devido à manutenção da estrutura que tinham no interior dos macrófagos (Juste \& Aduriz 1990). Quando a carga bacteriana é baixa, os bacilos podem não ser detectados no exame microscópico, o que poderia explicar os resultados negativos à coloração de Ziehl-Neelsen e positivos em outras técnicas. Nesse estudo, ZN foi satisfatória para a identificação do BAAR em esfregaços de fezes, em imprint de linfonodos mesentéricos e em raspado de mucosa intestinal dos búfalos. Vale ressaltar que os animais aqui estudados se encontravam na fase crônica da doença, na qual a eliminação das bactérias nas fezes é abundante, à semelhança do que ocorre com bovinos e ovinos.

Um dos aspectos de maior interesse do uso de técnicas da PCR, para detecção de Map, reside na baixa sensibilidade dos métodos culturais, uma vez que pode haver um número reduzido de bactérias nas amostras (Buckley \& Cashman 2009). Contudo, essa metodologia pode estar associada a algumas falhas como baixa especificidade e inibição da amplificação de DNA pela competição com bactérias contaminantes (Whittington 2009). Casos negativos devem ter seu DNA purificado e submetido a um novo teste para confirmação. No presente estu- do, a amplificação da sequência IS900-like foi possível, tanto nas amostras de mucosa intestinal quanto nas de linfonodo. O uso da PCR direta para detecção de Map nos rebanhos é muito útil, por ser uma técnica de grande sensibilidade, rapidez e baixo custo, quando comparada com métodos convencionais. Além disso, essa metodologia não requer processos confirmatórios e é confiável desde que controles negativos sejam utilizados (Clark et al. 2008). Sivakumar et al. (2005) também examinaram 20 búfalos com lesões histológicas sugestivas de paratuberculose na Índia e obtiveram 14 (70\%) e 6 (30\%) amostras positivas por PCR e cultura bacteriana, respectivamente. Tais resultados indicaram que a PCR foi mais sensível que a cultura na detecção da paratuberculose subclínica em búfalos.

No Brasil, a paratuberculose bovina foi descrita em alguns Estados e o aparecimento de novos casos sugere que o agente está se disseminando, principalmente nas raças leiteiras. Como não existem tratamento e vacina eficazes para controlar a doença, esta pode se tornar um sério problema sanitário para a pecuária no país.

\section{REFERÊNCIAS}

Acypreste C.S., Juliano R.S., Riveira F.E.B., Silva L.A.F., Fioravant M.C.S. \& Dias Filho F.C. 2005. Uso da técnica do ELISA indireto na detecção de anticorpos anti-Mycobacterium paratuberculosis em vacas em lactação. Cienc. Anim. Bras. 6(1):55-59.

Benson D.A. 2002. GenBank. Nucleic Acid Res. 30:17-20.

Brautingam F.E., Glass R. \& Mendy W. 1996. Levantamento sorológico utilizando a técnica de ELISA para paratuberculose em cinco rebanhos de corte do Mato Grosso do Sul e quatro de leite do Estado de São Paulo. $15^{\circ}$ Congresso Panamericano de Ciências Veterinárias, Campo Grande, MS, p.271.

Buckley J.F. \& Cashman W.J. 2009. Limitations of single test in the diagnosis of MAP. Vet. Rec. 164:282

Buergelt C.D., Hall C., McEntee K. \& Duncan J.R. 1978. Pathological evaluation of paratuberculosis in naturally infected cattle. Vet. Pathol. 15:196-207.

Clark Jr D.L., Koziczkowski J.J., Radcliff R.P., Carlson R.A. \& Ellingson J.L.E. 2008. Detection of Mycobacterium avium subspecies paratuberculosis: Comparing fecal culture versus serum enzyme-linked immunosorbent assay and direct fecal polymerase chain reaction. J. Dairy Sci. 91:2620-2627.

Clarke C.J. 1997. The pathology and pathogenesis of paratuberculosis in ruminants and other species. J. Comp. Pathol. 116:217-261.

Cventnic Z., Brlek K., Trstenjak J., Ocepek M., Spicic S. \& Mitak M. 2002. Economic importance of paratuberculosis in dairy cattle breeding. Proc. $7^{\text {th }}$ International Colloquium on Paratuberculosis, Bilbao, Spain, p.485-288.

Dias L.D., Assis R.A., Dias G.C.D., Junior A.C.O., Carvalho A.V.A., Pinto F.F., Gonçalves L.A., Martins N.E., Parreiras P.M. \& Nascimento R.P. 2002. Isolamento do Mycobacterium paratuberculosis a partir de fezes de bovinos suspeitos de paratuberculose. 11 ação Científica, Universidade Federal de Minas Gerais, Belo Horizonte.

Driemeier D., Cruz C.E.F., Gomes M.J.P., Corbellini L.G., Loretti A.P. \& Colodel E.M. 1999. Aspectos clínicos e patológicos da paratuberculose em bovinos no Rio Grande do Sul. Pesq. Vet. Bras. 19(3/4):109115

Dupont O. 1915. Jornal do Commércio do Rio de Janeiro de 5.11.1915. Ferreira R., Fonseca L.S. \& Lilenbaum W. 2001. Detecção de anticor- 
pos contra Mycobacterium paratuberculosis em rebanhos bovinos do Estado do Rio de Janeiro, Brasil. Revta Bras. Med. Vet. 23(4):19-24.

Fonseca L.F., Olival A.A., Pereira C.C., Heinemann M.B., Richtzenhain L.J. \& Santos M.V. 2000. Identificação de anticorpos anti-Mycobacterium paratuberculosis em rebanhos bovinos leiteiros do Estado de São Paulo. Arqs Fac. Vet. UFRGS. 28:51-56.

Gomes M.J.P., Driemeier D., Ribeiro V.R., Wunder Jr E.A., Asanome W., Lanzon L.F. \& Wald V.B. 2002. Doença de Johne: isolamento do Mycobacterium avim subsp. paratuberculosis (Map) em um rebanho leiteiro infectado na região sul do Brasil. Acta Scient. Vet. 30(2):113-118.

Juste R.A. \& Aduriz J.J. 1990. Diagnostico. Ovis 7:49-62.

Kramsky J.A., Manning E.J.B. \& Collins M.T. 2002. Binding of protein G to non-domestic hoofstock immunoglobulin and aplication in serodiagnosis of Johne's disease. Proc. $7^{\text {th }}$ International Colloquium on Paratuberculosis. Bilbao, Spain, p.187.

Kulshrestha R.C., Singh J. \& Chandiramani N.K. 1980. Haryana Vet. 19:139-141.

Lillini E., Gamberale F. \& Guardo G. 1999. Mycobacterium avium subsp. paratuberculosis infecction in water buffalo (Bubalus bubalis) from Central Italy. Proc. $6^{\text {th }}$ International Colloquium on Paratuberculosis, Melbourne, Australia, p.254.

Manning E.J.B. \& Collins M.T. 2001. Mycobacterium avium subsp. paratuberculosis: Pathogenesis and diagnosis. Rev. Sci. Tech. Off. Int. Epizoot. 20:33-150.

Mota R.A., Pinheiro Junior J.W., Gomes M.J.P., Peixoto R.M., Maia F.C.L., Brito M.F., Chies J.A.B., Snel G.G.M., Bercht B.S. \& Juffo G.D. 2007. Paratuberculose em um rebanho leiteiro no Estado de Pernambuco. Arqs Inst. Biológico, São Paulo, 74(2):73-74.

Nakajima M., Maia F.C.L. \& Mota P.M.P.C. 1991. Diagnóstico da paratuberculose em Minas Gerais. 4ํㅗㅇㅡósio Brasileiro em Micobactérias, Bauru, SP, p.67. (Resumo)

Oliveira D.M., Pimentel L.A., Rodrigues T.A., Dantas, A.F.M., Miranda Neto E.G., Simões S.V.D. \& Riet-Correa F. 2008. Paratuberculose em bovinos no Estado da Paraíba. Encontro Nacional do Diagnóstico Veterinário, Campo Grande, MS, p.203-204. (CD-ROM)

Portugal M.A.S.C., Pimentel J.N., Saliba A.M., Baldassi L. \& Sandoval E.F.D. 1979. Ocorrência de paratuberculose no Estado de Santa Catarina. Biológico 4:19-24.

Ramos E.T., Poester F.P., Correa B.L., Oliveira S.J., Rodrigues N.C. \& Cabarro C.E. 1986. Paratuberculose em bovinos no Estado de Rio Grande do Sul. Hora Vet. 6(34):28-32.

Raut A., Manju A., Kumar B. \& Sethi R.K. 2003. Prevalence of paratuberculosis in breeding buffalo bulls at organized farms. Proc. $4^{\text {th }}$ Asian Buffalo Congress on Buffalo for Food Security and Rural Employment, New Delhi, India, p.18.

Sambrook J. \& Russell D. 2001. Molecular Cloning: A laboratory manual. Cold Spring Harbor Laboratory Press, New York, p.62.

Santos J.A. \& Silva N.I. 1956. Sobre a 1aㅡ observação de paratuberculose no Brasil. Bolm Soc. Bras. Med. Vet. 24:5-14.

Silva E.B. 2005. Diagnóstico de paratuberculose em bovinos de corte do estado do Pará-Brasil. Dissertação de Mestrado em Ciência Animal, Universidade Federal do Pará, Belém. 55p.

Sivakumar P., Tripathi B.N. \& Singh N. 2005. Detection of Mycobacterium avium subsp. paratuberculosis in intestinal and lymphnode tissues of water buffaloes (Bubalis bubalis) by PCR and bacterial culture. Vet. Microbiol. 108:263-270.

Sivakumar P., Tripathi B.N., Singh N. \& Sharma A.K. 2006. Pathology of naturally occurring paratuberculosis in water buffaloes (Bubalus bubalis). Vet. Pathol. 43:455-462.

Taddei R., Barbieri M.L., Fallacara F., Belletti G.L. \& Arrigoni N. 2008. Mycobacterium porcinum strains isolated from bovine bulk milk: Implications for Mycobacterium avium subsp. paratuberculosis detection by PCR and culture. Vet. Microbiol. 130:338-347.

Whittington R.J. 2009. Factors affecting isolation and identification of Mycobacterium avium subsp. paratuberculosis from fecal and tissue samples in a liquid culture system. J. Clin. Microbiol. 47(3):614-622. 